\title{
Current trends in Russia's cooperation in the global organic market (legal aspects)
}

\author{
Olga Grigorieva ${ }^{1, *}$ \\ ${ }^{1}$ Moscow State Institute of International Relations, Moscow, Russia
}

\begin{abstract}
The article analyzes trends in the development of Russian legislation aimed at ensuring Russia's competitiveness in the world market of organic producers. Questions of compliance of Russian legislation on organic matter with international standards of FAO UN are studied. Analysis of statistical data from the Russian Ministry of agriculture and the National organic Union showed a sharp decline in exports of agroindustrial complex products in 2020 compared to 2017-2019. This is happening against the background of rapid development of the global organic market. Modern trends of state regulation to overcome the decline in exports and their impact on Russia's place in the world organic market are studied.
\end{abstract}

\section{Introduction}

Russia's agriculture has undergone significant institutional changes: denationalization, decollectivization, enlarging holdings, agro-industrial integration, land and capital concentration. They were the drivers of growth and provided an increase in production, exports, and productivity. For centuries, Russia has lived with starvation or lack of products of its production. Today, the country is almost completely provided with basic foodstuffs. The transition to an export development model is a confirmation of positive changes and the emergence of the agri-food sector to a new level of sustainability.

According to the Russian Ministry of agriculture, the Russian Federation is currently ranked 19th in the ranking of the world's major food exporters. In comparison with 2010, exports increased 3 times, and in comparison with 2000, almost 19 times [1].

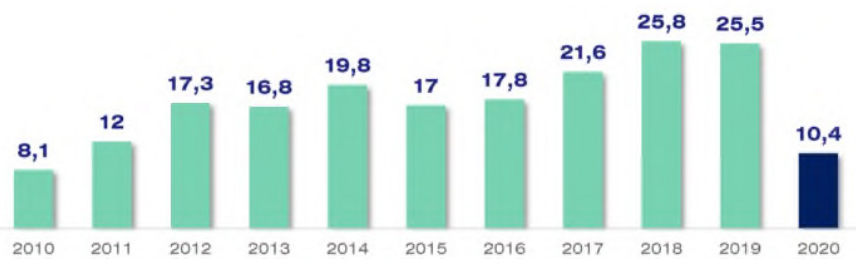

Fig. 1. Export of products from Russia in 2020 (billion \$).

\footnotetext{
* Corresponding author: 5618861@mail.ru
} 


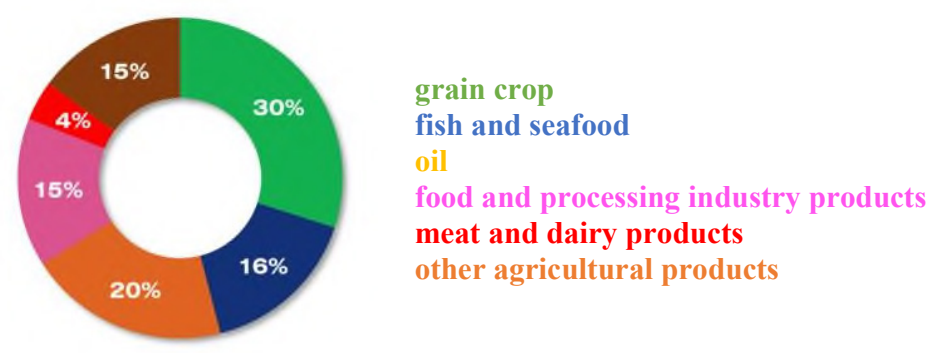

Fig. 2. Structure of agricultural exports from Russia in 2020 (\%).

With an obvious drop in exports, Russia faces a global challenge - to bring the volume of export of agricultural products to 45 billion dollars per year by 2024 . The solution of this problem not only changes Russia's role in world agricultural production qualitatively, it requires a deep understanding of global world and domestic Russian processes in the agrifood sphere.

The introduction of new technologies in agricultural production is an alternative to the development of the agro-industrial sector, which allows us to contest more successfully both on the Russian and international markets, increases the Biosafety, quality and attractiveness of work in the agro-industrial complex. These factors are crucial for the development of Russian regions.

One of the factors that positively affects the effective solution of these problems is the legal security of the production and sale of organic foods.

The idea of a healthy diet has long been established abroad. The issues of production, sale and consumption of organic products are discussed by scientists, producers, marketers, and dietitians $[2,3]$.

Is organic a short-term trend or a serious step for Russia towards Russia's global technological leadership in the agro-industrial complex? Today, this issue is being discussed at the highest level of government, in the scientific community, and in associations of agricultural producers.

In 2018, investments in agriculture and related industries totaled 474 billion rubles. The Russian government has set a goal to increase this amount to 822 billion rubles in 2024 , which means an increase of $73 \%$.

One of the fastest growing segments should be food products, where investment is planned to increase from 201 to 356 billion rubles, or by $77 \%$ [4].

These tasks are without exaggeration very ambitious, since agriculture, unlike natural resourced-based sectors, cannot be attributed to the most marginal sectors of the Russian economy.

However, these tasks must be met to ensure that the country's social and economic development goals are met.

Today, there are absolute trends in investing in companies that produce "fast food" (noodles, soups, etc.), cooking at home from ready-made sets of products, and in the first place - companies that deliver ready-made food ("processed" food). Investments are growing in companies that prepare food for consumers with allergies and vegetarians, including in the production of meat from plant components (soy, peas, etc.), "glue" meat (grown in laboratories), and sugar substitutes. 


\section{Materials and Methods}

The sources are the international organic standards FAO UN and IFOAM; The Law "On organic products", which entered into force on January 1, 2020 [5]. The Law introduces the concepts of organic products and organic agriculture, regulates the production, storage, transportation and sale of organic products. The article uses the practice of certification of organic products in Russia, including certification of imported organic products, the State center for certification, standardization and Metrology (Rostest), Federal state institution "Rosselkhoznadzor center", Organization "Roscachestvo", Limited Liability Company "Organic expert". The article uses statistical data and information on investments in the development of agriculture and related industries of and the Union of organic agriculture of Russia.

\section{Results}

Russia's rise to a leading position in the world in ensuring food security is a distant prospect. This process is largely due to the active transition to organic food in accordance with the standards set by FAO UN and IFOAM.

According to experts of the National organic Union of Russia, the largest number of organic producers is in India, Uganda, Ethiopia and Tanzania [6].

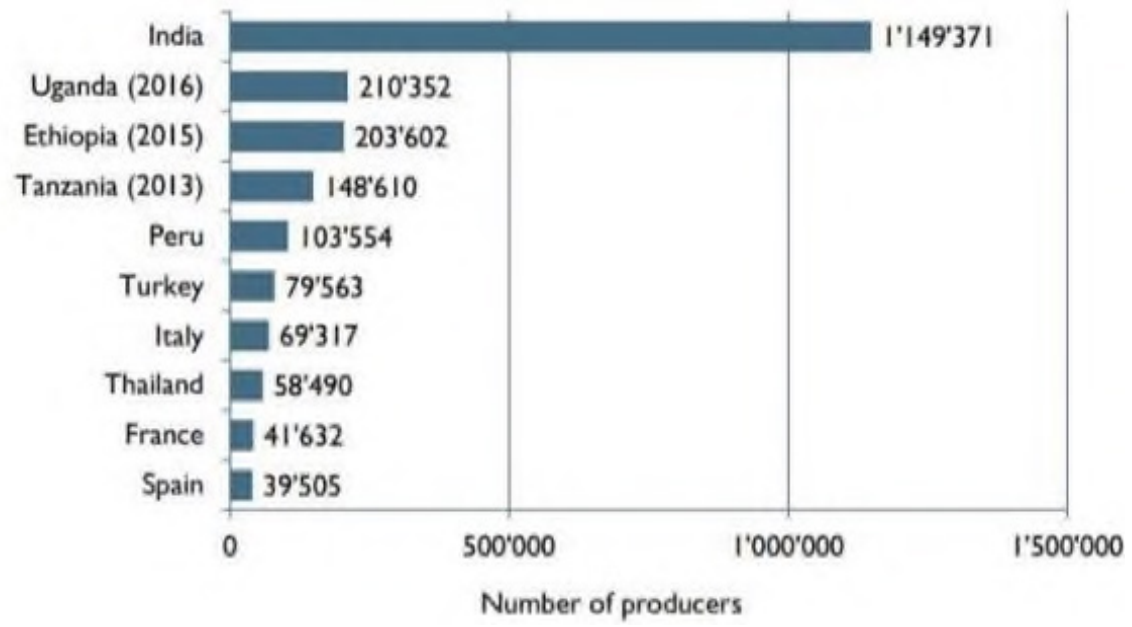

Fig. 3. A rating of countries-producers of organic matter.

Russian legislation on organic foods is just beginning to form. The organic market itself is also in its infancy. This stage is commonly referred to as the transition period to organic agriculture and organic production. During the transition period, the implementation of rules for organic farming and organic production established by national, interstate and international standards in the field of organic production in the Russian Federation is ensured. It is not allowed to mark organic foods on the packaging and packaging of products produced during the transition period.

On January 1, 2020, the Federal law [5] on organic products entered into force, which regulates relations for the production, storage, transportation, labeling and sale of organic products. The law establishes a number of requirements that must be met in the production of organic products (separation of production, prohibition of the use of genetic engineering, 
prohibition of the use of agrochemicals, pesticides, antibiotics, stimulants, except for permitted ones, etc.).

In order to inform consumers about organic foods free of charge, a unified state register of organic producers is being created. The information contained in it is publicly available and is published on the official website of the Ministry of agriculture of Russia in the form of open data.

Producers of organic foods have the right to use a special marking, which is a distinctive feature of organic foods, after confirming the conformity of production.

Organic products must be labelled as follows:

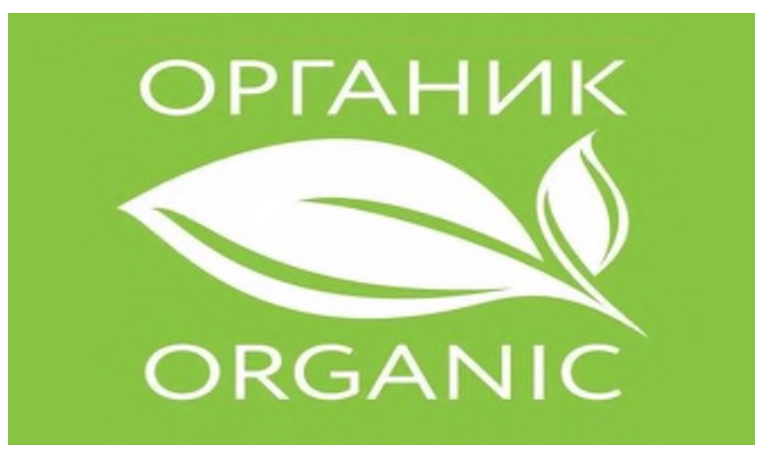

Fig. 4. Labeling of organic products.

As stated in this Law, the legal regulation of relations in the field of organic production is based on the acts that make up the law of the Eurasian economic Union, Russian legislation, and the legislation of the subjects of the Russian Federation.

In addition to the organic law, the Federal law "on technical regulation" of 2002 [7] regulates the "voluntary confirmation of conformity" of products, works and services. Confirmation of conformity of organic production is also carried out in the form of voluntary certification. Voluntary confirmation of conformity does not replace mandatory confirmation of conformity of organic foods in cases stipulated by the acts of the Eurasian economic Union and the legislation of Russia.

In 2019, the orders of the Ministry of agriculture of Russia approved the procedure for maintaining the open state register of organic producers, the procedure and form of using the organic product mark.

An urgent problem of legal regulation of the organic market in Russia is the mutual recognition of standards for organic foods.

The international Federation of organic agriculture movements (IFOAM) unites more than 100 organizations from many countries of the world. In order for Russian legislation in the field of organics to be recognized at the international level, it must comply with international standards.

Today in Russia there are three national standards for organic products:

1)“Organic products. Rules of production, processing, labeling and sale “(2016) [8];

2) "Procedure for voluntary certification of organic products" (2016) [9];

3)“Organic food products. Terms and definitions" (2014) [10].

These standards were adopted before the entry into force of the law on organic products, and they need to be improved and brought into line with international IFOAM standards.

IFOAM's regulatory requirements include three documents:

- Common goals and requirements of organic standards (COROS) - Common IFOAM requirements;

- IFOAM standard for organic production and processing systems; 
- IFOAM-approved accreditation requirements for certification bodies that control organic production and processing [11].

The IFOAM organic production guarantee system promotes international trade, maintains the purity of organic production, and inspires the confidence of buyers around the world.

In their efforts to enter the international market, Russian organic products, even before the law on organic products came into force, adhered to the following European standards in their practice:

- Commission Regulation (EC) No 889/2008 of 5 September 2008 laying down detailed rules for the implementation of Council Regulation (EC) No 834/2007 on organic production and labelling of organic products with regard to organic production, labelling and control;

- Council Regulation (EC) No 834/2007 of 28 June 2007 on organic production and labelling of organic products and repealing Regulation (EEC) No 2092/91;

- Regulation (eu) 2018/848 of the European parliament and of the council of 30 may 2018.

On this occasion, IFOAM Ambassador, Executive Director of IFOAM 1987-2005 and organic farmer G. Bernward said: "This is a solidarity movement. Russia has turned to our standards. On this basis, we can make sure that Russia actively represents Eurasia, and the Russian organic movement should show even more of its presence, participate more actively in international meetings and show what is happening in Russia in the organic sector" [12].

Another problem on Russia's way to the world market of organic products is the lack of a clear system of domestic certification bodies. This problem of a managerial nature makes significant difficulties in the activities of organic producers. This, along with other factors, determines the high cost of organic products.

From 2020, all organic products must pass the appropriate certification procedure, which will result in producers receiving official permission to sell them. Without a certificate, the sale of this product is illegitimate and as a result it will be withdrawn from circulation. For producers of organic matter in the absence of certification leads to significant losses. This rule also applies to foreign organic producers who have international certificates and wish to sell it on the territory of Russia. The share of organic imports in the Russian food market is $80 \%$ of all bioproducts. Starting from 2020, all foreign bioproducts on the Russian market must have Russian certificates, even if there is an international certificate.

In Russia, only special organizations that have passed state accreditation in the field of organic production can issue a certificate for organic products. Currently in Russia only three organizations have the right to provide this service:

- Federal state institution "Rosselkhoznadzor center" - for crop production;

- Is a non-profit organization "Roscachestvo" - in crop production, livestock, processing;

- Limited Liability Company "Organic expert" - for crop production, animal husbandry, processing (accreditation was suspended in 2019).

Thus, in addition to imperfect legislation, the development of the organic market in Russia is hindered by a poorly organized system of certification bodies.

\section{Discussion}

The Russian Ministry of agriculture is concerned about increasing the competitiveness of agriculture. In turn, this affects Russia's place in the world ranking of organic producers. 
Among the basic factors of increasing the competitiveness of the grain industry, the following are highlighted.

Today, Russia has initiated the formation of legislation on organic products, as well as a system of certification bodies for such products. However, there are still many problems that are actively discussed by scientists and practitioners. These include ways to further develop legislation on organic products in accordance with international IFOAM standards, ease and accessibility of certification of organic products, and securing the validity of foreign certificates in the territory of Russia.

Another dicussion problem is the use of biofertilizers in the production of organic products. In accordance with international standards and Russian legislation, organic production requires the use of biofertilizers. According to the head of the Federal state institution "all-Russian research Institute of biological plant protection" A. Asaturov, there are still very few certified biologics suitable for organics [13]. It is necessary to introduce a system of preferences for registering biologics in comparison with chemical fertilizers. As of today, the registration fee for all candidates is the same. Another problem is the quality monitoring and certification, it requires a rigor that consumers of organic products was confident in their quality.

In foreign literature, the problem of certification and use of bio-fertilizers in the production of organic products has been discussed for many years [14-16]. In Russia, these problems are new, since the organic market itself is just being formed. But they should also be addressed by law.

FAO UN constantly encourages States to switch to organic agriculture and the use of biofertilizers. At one time, the use of chemical fertilizers in agriculture significantly contributed to the growing shortage of food in developing countries, in particular on the African continent. According to the RFI Kiswahili news Agency, speaking in the city of Dar es Salaam, the FAO representative in Tanzania, Fred Kafero, said that organic agriculture increases farmers ' productivity, increases food security, and helps to resist climate change and take care of the environment [17].

\section{Conclusion}

Today, Russia remains an importer of organic products, and about $80 \%$ of such products (apples, potatoes, flour and cereals) are imported from other countries. At the same time, Russia has a huge potential for organic production: there are large environmentally friendly land resources, labor force, legislation on organic products is being formed; society has an understanding of proper nutrition and a healthy lifestyle, and, consequently, the need for organic products.

It is necessary to increase the state's attention to the problem of increasing the growth of organic production, since in Russia the main investments in this industry are private.

A healthy diet is a healthy life, as well as a healthy nation. A formula that every state, including modern Russia, strives to apply in its own country.

\section{References}

1. Analytical review "AgroExport 2030. Trends and prospects" https://mcx.gov.ru/upload/iblock/186/186a255a5aefae001e3d6fle7a93089d.pdf

2. J. Anding, P. Crandall, The Consumers' Perspective on the Safety of Organic Foods: An Opportunity for Future Research. In Ricke S. \& Jones F. (Eds.), Perspectives on Food-Safety Issues of Animal-Derived Foods (Fayetteville, AR: University of Arkansas, 323-334, 2010) 
3. S. V. Packard, "Natural/Organic Foods." Processed Foods and the Consumer: Additives, Labeling, Standards, and Nutrition, by Vernal S. Packard (NED - New edition ed., Minneapolis: University of Minnesota Press, 1976)

4. 21th Russian agro-industrial exhibition. Business program. https://goldenautumn.moscow/eksponentam/delovaya-programma.html

5. Federal law of the Russian Federation "On organic products and amendments to certain legislative acts of the Russian Federation" $(280,2018)$

6. Russia's organic market in 2020 (according to the National organic Union) http://rosorganic.ru/files/Analiz\%20organic\%20RF\%202020\%20г.pdf

7. Federal law of the Russian Federation "On technical regulation" $(184,2002)$

8. National standard of the Russian Federation GOST 56508-2015 “Organic products. Rules of production, processing, labeling and sale" (2016) http://mcx.ru/upload/iblock/21f/21f18ef2695f6d848c77d0b3e5d3aca4.pdf

9. National standard of the Russian Federation GOST P 57022-2016 "Procedure for voluntary certification of organic products" (2016) http://docs.cntd.ru/document/1200138287

10. National standard of the Russian Federation GOST P 56104-2014 "Organic food products. Terms and definitions" (2014) http://docs.cntd.ru/document/1200113488

11. IFOAM. (n.d.) https://www.ifoam.bio

12. Plenary session on "Organic agriculture in Russia on the eve of the entry into force of the law on organic products" https://news.metrologu.ru.html

13. "Without competitive certification, the organic market will rise": experts discussed the prospects for the development of organic agriculture in Russia. (2019) http://rosorganic.ru/about/press/without-competitive-certification-o.html

14. G. Ros, A. Van Rotterdam, D. Bussink, P. Bindraban, Selenium fertilization strategies for bio-fortification of food: An agro-ecosystem approach, Plant and Soil, 404(1/2), 99112 (2016)

15. S. Sribir. (2007). Bio-Molecules as Bio-Fertilizers: Safe Food for Better Health, Current Science, 93, 9, 1202-1203 (2007)

16. S. Heinze, M. Oltmanns, R. Joergensen, J. Raupp, Changes in microbial biomass indices after 10 years of farmyard manure and vegetal fertilizer application to a sandy soil under organic management, Plant and Soil 343(1/2), 221-234 (2011)

17. FAO UN. (n.d.) http://www.fao.org/about/en/ 